\title{
Lojistik Bölümünü Tercih Eden Öğrencilerin Lojistik Sektöründen Beklentileri: Karamanoğlu Mehmetbey Üniversitesi Örneği
}

DOI: 10.26466/opus.679831

\author{
Ahmet Alper Sayın* - Ümmü Küçük ** \\ * Dr.Öğr.Üyesi, Karamanoğlu Mehmetbey Üni., Uygulamalı Bilimler Y.O, Uluslararası Ticaret ve \\ Lojistik Yönetimi, Karaman/TÜRKIYYE \\ E-Posta: ahmetalpersayin@kmu.edu.tr \\ ORCID: $0000-0002-2086-6763$ \\ ** Yüksek Lisans Öğrencisi, Karamanoğlu Mehmetbey Üniversitesi, Uygulamalı Bilimler Y.O, \\ Uluslararası Ticaret ve Lojistik Yönetimi ABD, Karaman/TÜRKIYE \\ E-Posta: ummukucuk5@gmail.com \\ ORCID: $\underline{0000-0003-0334-0820}$
}

Öz

Lojistik sektörü, son yillarda hızla gelişmeye devam eden bir sektördür. Ekonomik şartlar, artan ticaret hacmi, değişen pazar ve müşteri yapısı, artan ve zorlaşan rekabet koşulları dünya çapında bir hizmet sektörü olan lojistik sektörünü her zamankinden daha önemli hale getirmiştir. Bu bağlamda çalışmanın amacı, öğrencilerin lojistik sektörüne bakışı, aldıkları eğitimin, çevre etkisi ve lojistik sektöründe kariyer olanaklarının, lojistik sektöründe çalışma niyetine etkisi üzerine ilişkisini, incelenmesi amaçlanmaktadır.Araştırmada anket yöntemiyle Karamanoğlu Mehmetbey Üniversitesinde önlisans/lisans programlarında lojistik bölümünde okuyan ve mezun olan 232 ögrrenciden veri elde edilmiş̧ir. Elde edilen verilerin analiz edilmesinde güvenilirlik, faktör analizi, ve geçerlilik analizi kullanılmış ve araştırma hipotezlerinin test edilmesinde yapısal eşitlik modellemesinden faydalanılmıştır.Analiz sonucunda; öğrencilerin lojistik sektörüne bakışı lojistik sektöründe kariyer yapma isteğini pozitif yönde anlamlı olarak etkilediği; öğrencilerin okulda aldıkları eğitimin lojistik sektöründe kariyer yapma isteğini pozitif yönde anlaml olarak etkilediği; öğrencilerin çevre etkisinin lojistik sektöründe kariyer yapma isteğini pozitif yönde anlaml olarak etkilediği; öğrencilerin lojistik sektöründe kariyer yapma isteği ile lojistik sektöründe çalışma niyetini pozitif yönde anlamlı olarak etkilediği_bulgularına ulaşılmıştır.

Anahtar Kelimeler: Lojistik, Lojistik sektörü, Öğrenci beklentileri 


\title{
Expectations of Students Who Prefer Logistics Department from Logistics Sector: Example of Karamanoğlu Mehmetbey University
}

\begin{abstract}
The logistics sector is a sector that has been developing in recent years and continues to develop rapidly. Economic conditions, increasing trade volume, changing market and customer structure, and increasing and difficult competition conditions have made the logistics sector, which is a worldwide service sector, more important than ever. In this context, the purpose of the study is to examine the students' view on the logistics industry, the relationship they receive, the effect of the environment and career opportunities in the logistics industry on the impact of the intention to work in the logistics industry. In the research, data were obtained from 232 students who graduated from Karamanoğlu Mehmetbey University in associate / undergraduate programs and graduated from the logistics department. In analyzing the data obtained: reliability, factor analysis and validity analysis were used, and structural equation modeling was used to test the research hypotheses. As a result of the analysis; students' view of the logistics sector positively and significantly affect their desire to pursue a career in the logistics sector; that students' education at school positively affects their desire to pursue a career in logistics; the environmental impact of students positively and significantly affect the desire to pursue a career in logistics; It was found that students' desire to have a career in logistics sector positively and significantly affect their intention to work in logistics sector..
\end{abstract}

Keywords: Logistics, Logistics sector, Student expectations 


\section{Giriş}

Günümüz dünyasında değişen ekonomik şartlar, artan ticaret hacmi, değişen pazar ve müşteri yapısı, artan ve zorlaşan rekabet koşulları ve bütün bu bileşenlerin küresel hale gelmesi neticesinde lojistik sektörü, geçmiş yıllara göre daha önemli hale gelmiştir. Bu değişimle birlikte lojistik sektörü hizmet sektörleri içinde pazar payı sürekli artan bir trend yakalamıştır (Koban, 2018, s.24). Değişen dünyada küreselleşmenin de etkileriyle birlikte karşılıklı etkileşimler artmaktadır. Etkileşimlerin artması neticesinde lojistik sektörü en hızlı gelişim gösteren sektörlerden birisi konumuna gelmiştir (Tekin, 2019, s.13).

İşletmeler sadece fiyat, kalite, maliyet gibi faktörlerle savaşmamaktadır. İçinde bulunduğumuz bilgi çağında, hızla gelişen teknolojinin de etkisiyle müşterilerin istek ve beklentileri artmaktadır (Polat, 2018, s.1). Hem içerisinde kapsadığı faaliyetlerin fazla olması hem de doğrudan üretim, pazarlama ve uluslararası ticaret firmaları ile de bağlantılı olması nedeni ile kişiler arası, şirketler arası ya da kişi ve şirketler arası geniş bir ilişki ağına sahiptir (Ayata, 2019, s.17).

Lojistik sektörü son yıllarda süreç, alt yapı ve teknoloji açısından hızla gelişmeye devam eden bir sektördür. Bu sebeple ülkemizde uygulanmaya başlayan lojistik faaliyetleri, işletmeleri rekabet ortamına sürüklemiştir (Dalgıç, 2019, s.14). Lojistik, sipariş işleme, satın alma, ulaşım, üretim planı ve programı, envanter yönetimi, teslimat, dağıtım, depo yönetimi, malzeme ihtiyaç planlanması, yönetimin müşteriye cevap vermesi gibi bilgi sistemlerini yönetmektedir (Tuerxun, 2017, s.17).

Lojistik sektörü, ülkemiz ekonomisi için de büyük önem taşımaktadır. Türkiye'nin ticaret hacminin giderek yükselmesi neticesinde, lojistik sektörü çok hızlı bir gelişme göstermekte ve istihdam yaratmaktadır (Polat, 2018, s.1).

Bu çalışmanın amacı lojistik öğrencilerinin lojistik sektöründen beklentileri üzerinde odaklanmak ve sektör hakkında araştırmalar yaparak iş olanakları, istihdam ve kariyer düzeyinin ne derecede olduğu hakkında bilgilendirme yapmak amaçlamıştır. 


\section{Lojistik Sektörü ve Tarihsel Gelişimi}

Lojistik bugüne kadar birçok aşamadan geçmiştir. İlk çıktığı yıllarda hiç bilinmemekte ve bu yüzdende gelişme gösterememektedir. Sanayi devrimi ile başlayarak bugüne kadar gelmeyi başarmıştır. Lojistik günümüz şartlar ve imkânlarında da etkilenmeye devam ederek gelişmesini sürdürmektedir.

Günümüzde lojistiğin kapsamına; taşıma, depolama, müşteri hizmetleri, pazarlama, sigorta, satış gibi farklı işlemlerde girmektedir. Lojistik çok geniş bir alana sahiptir. Dünyada yaşanan değişimler ve gelişmeler incelendiğinde bu kapsamın daha da genişleyebileceği düşünülmektedir (Uğur, 2019, s.41).

Lojistik sektörü, ticari hayattaki tüm sektörlerle doğrudan ve dolaylı olarak bağlantılı olması nedeni ile de kapsamı geniştir. Kapsamının geniş olmasının dezavantajı olarak da, uyuşmazlık hususlarının yoğun olarak karşılaşıldığı işletmeleri de bünyesinde barındırmaktadır. Karşılaşılan uyuşmazlıklarda, ihtiyari arabuluculuk yöntemini uyguluyor olmaları ve zorunlu arabuluculuk sürecine de dâhil olmaları nedeni ile de arabuluculuk yönteminin en fazla uygulandığı ve uygulanacağı en genişs sektör olmaktadır (Ayata, 2019, s.18).

Lojistik sektörü 20.yy başlarında iş tercihinde çok tercih edilmeyen hatta bilinmeyen bir sektör olup çok önem verilmemiştir. 2. Dünya savaşına kadar işletmelerde lojistik faaliyetlerin tamamından ziyade taşımacılık faaliyeti daha çok uygulanmanmıştır uygulanmamıştır. Amerika Birleşik Devletlerinde başlayarak, Avrupa'ya da Amerikan şirketleri aracılığıyla geçen bu hizmet ülkemizde temel işlemlerin taşımacılık olan nakliyeci kurumlarının veya temel işleri depolama olan depolama kurumlarını isimlerinin ek olarak bir Lojistik kelimesi getirmeleri ile başlamıştır (www.borusanlojistik.com).

Lojistik; taşıma, gümrükleme, depolama, elleçleme, sigortalama, ambalajlama ve talep planlaması gibi faaliyetlerle, başta sanayi olmak üzere tüm sektörlere hizmet sunarak tüm sektörleri doğrudan ve dolaylı olarak etkilemektedir (Ayata, 2019, s.17).

Dünyada gelişen ülkeler birbirleri ile bütünleşik durumdadır. Ülkemizde ise 1980 ve 1990 yıllarında karadan, havadan, denizden, demiryolundan ve kombine olarak yapılan lojistik faaliyetlerde göstermiş olduğu gelişmeler sayesinde yatırımlar artış göstermiştir. Daha sonra lojistik sektörü 1990 yılında daha da gelişme göstermeye devam etmiştir. Türkiye'de lojistik sektörü yaşanan bu gelişmelerin ardından 2000 yılı itibari ile uluslararası alanda ve yerli 
firmalarla işbirliği içinde bulunarak yurtdışında da bürolar açmıştır ve kalitesini sürekli arttırarak adını duyurmuştur (Babacan, 2003, s.10).

Lojistik sektörü ve kapsamı yıllar ilerledikçe yeni şekillere bürünmüştür (Unctad, 2006, s.4). Lojistik ilk üretim yerinden son tüketim yerine kadar ürünün gidişatını sağlayan faaliyetler olarak bilinirken (Lambert Stock, Ellram, 1998, s.15) şimdilerde lojistik belirlemiş olan hedefe ve piyasaya gerekli mallar için taşıma, stok yönetimi ve sipariş işleme gibi faaliyetleri içermektedir (Rodrigue ve Hesse, 2007, s.3).

Lojistik sektörünün tarihsel gelişimini incelersek;

1950 yılı öncesi: 1950'e kadar dünya da genel olarak firmalar lojistik kelimesini bilmemekte ve faaliyetlerini farklı birimlerde ve daha farklı sorumluluklar çerçevesinde faaliyetlerine devam etmektedir. Genel olarak bu bölümlerin hedefleri birbiri ile çatışmakta ve birlikte hareket etmeyi güçleştirmektedir. 20. yüzyılın başında pazarlama kavramının öneminin artması ile birlikte lojistiğin de değeri artmıştır.

1950-1960 Dönemi: 1950 ve 1960 dönemlerinde dağıtım faaliyetleri plansız ve düzensiz bir şekilde ilerlemektedir. Bu dönemde, üreticilerden perakendecilere üretilen mallar bir şekilde dükkâna ulaşmaktaydı. Kontroller ve dağıtımlarla ilgili çeşitli fonksiyonlar arasında bağlantı bulunmamaktadır.

1960-1970 Dönemi: Firmalar, müşteri sadakatini yakalamak ve oluşturmak için pazarlama stratejileri geliştirmeye başlamışlardı. Bu değişikliği tetikleyen neden ise kitle üretimden geniş ve çeşitli boyutlu üretime geçilmiş olmasıdır.

1970-1980 Dönemi: Bu dönemde dağıtım kavramı şekil almaktadır. Bazı firmalar da kendi dağıtım alanlarında büyük perakende zincirleri geliştirmeye başlamıştır.

1980-1990 Dönemi: Lojistik kavramı 1985 yılında büyük çaplı kullanılmaya başlanmıştır. Daha sonra da "Tedarik Zinciri Yönetimi'ne" ( TZY ) geçilmiştir. Tedarik Zincirine geçilmesinin sebebi 1980 yıllarından sonra bilgi sistemleri ve iletişim sektöründe yaşanmakta olan hızlı gelişmelerdir. 1981'de Amerika Birleşik Devletlerinde telekomünikasyon sektörünün deregülasyonu ile 
beraber bilgi iletişim ve teknolojilerinin kullanım artmıştır. Taşımaclık sektörünün deregülasyonu da bu döneme denk gelmektedir. Taşımacılıkta deregülasyonla fiyat esnekliği ortaya çıkmaktadır.

1990-2000 Dönemi: 1990 yıllarının başında firmalar, yeni pazar mücadelelerine karşı tepki vermek için üretim yeteneğini değiştirerek entegre lojistik yönetimi faaliyetlerini genişletmeye başlamış ve tedarik zinciri yönetiminde tüm şirketleri bir dizide toplamaya yöneltmiştir.

2000 yılı ve sonrası: Bu dönemden sonra lojistik, işletme stratejilerinin önemli bir rekabet avantajı sağlamada önemli bir etken haline gelmiştir (www.lojisturk.net).

Teknolojinin gelişmesi, iş olanaklarının artması ile lojistik sektöründe de yeni gelişmeler yaşanmıştır.

Tablo-1'de lojistik üç dönemde ayrılmış ve bu dönemlerde lojistiğin nerelerde kullanıldığı belirtilmiştir. Birinci dönemde lojistiğin askeri alanlarda kullanıldığı belirtilmiştir. İkinci dönem ise ticaret lojistiği dönemidir ve bu dönemde lojistik kavramı ticaret alanında kullanılmaktadır. Üçüncü ve son dönemde ise modern lojistik gelmektedir. Bu dönemde kendi arasında iki ayrı başlık altında toplanmıştır. İk olarak yönetsel lojistik gelmektedir ve yönetsel lojistikte kendi arasında başlıklara ayrılmıştır bu başlıklar tedarik yönetimi ve lojistik yönetimidir. Diğer bir başlık ise operasyonel lojistiktir. Operasyonel lojistikte kendi içerisinde ayrılmıştır. Bu alanlar materyal yönetimi, üretim-operasyon yönetimi ve dağıtım yönetimidir.

\section{Tablo 1. Lojistiğin dönemsel olarak gruplandırma tablosu}

\begin{tabular}{|c|c|c|}
\hline I.DÖNEM & II. DÖNEM & III. DÖNEM \\
\hline LOJISTIK & TİCARET LOJİSTIĞİ & MODERN LOJISTIKK \\
\hline \multirow[t]{7}{*}{$\begin{array}{l}\text { Lojistiğin Askeri faaliyetlerde } \\
\text { kullanıldığı dönem. }\end{array}$} & $\begin{array}{l}\text { Lojistiğin Ticari faaliyetlerde } \\
\text { kullanıldığı dönem. }\end{array}$ & 1.Yönetsel Lojistik \\
\hline & & a-Tedarik Yönetimi \\
\hline & & b-Lojistik Yönetimi \\
\hline & & 2.Operasyonel Lojistik \\
\hline & & a-Materyal Yönetimi \\
\hline & & b-Üretim-Operasyon Yönetim \\
\hline & & c-Dağıtım Yönetimi \\
\hline
\end{tabular}

Kaynak: (Tutar vd., 2009, s.193). 


\section{Dünya'da Lojistik Sektörü}

Lojistik sektörü küreselleşmenin de etkisiyle dünya piyasasına önemli katkı sağlamaktadır ve gelişim dönemi ile hizmet ve sanayi sektöründen sonra üçüncü sektör olarak yer almaktadır (Tuerxun, 2017, s.14).

Dünya lojistik sektörünün kapasitesi, yaklaşık 5 trilyon dolardır ve üretimi gerçekleşen her bir dolarlık değerin en az \%25'i lojistikteki uygulamalardan elde edilmektedir. Avrupa Birliği lojistik sektörü, yaklaşık 627 milyar Euro değerindedir.

LPI'nın en son yayımlanan 2016 yılı sonuçlarına göre; 160 ülke arasında Almanya, 4,23 skoru ile 1 . Suriye 1,60 skoru ile 160 . sırada yer alırken, Türkiye 3,42 derece ile 34. sırada yer almaktadır (Özkanlısoy, 2018, s.23).

2018 yılı için belirtilen Lojistik Performans Endeksi istatistiklerine göre Türkiye, 160 ülke içinde 47. sırada yer almaktadır. Diğer senelerde karşılaştırma yapıldığında Türkiye'nin bugüne kadar olan en kötü performansı 2018 yılında görülmektedir. Hem bu sıralamada hem LPI puanında Türkiye'nin 2016 yılı ile karşılaştırıldığında Türkiye ilerleme gösterememektedir ve hatta önemli derecede gerileme yaşanmaktadır.

Tablo 2. 2018 Türkiye performans endeksi tablosu

\begin{tabular}{lllllllll}
\hline Y1l & Sıra & $\begin{array}{l}\text { LPI } \\
\text { Puanı }\end{array}$ & Gümrük & $\begin{array}{l}\text { Alt- } \\
\text { yapı }\end{array}$ & $\begin{array}{l}\text { Uluslara- } \\
\text { rasi } \\
\text { Sevkiyat }\end{array}$ & $\begin{array}{l}\text { Lojistik } \\
\text { Hizmetleri } \\
\text { Kalitesi }\end{array}$ & $\begin{array}{l}\text { Gönderilerin } \\
\text { İzlenebilirliği } \\
\text { ve Kalitesi }\end{array}$ & $\begin{array}{l}\text { Gönderilerin } \\
\text { Zamanında } \\
\text { Teslimi }\end{array}$ \\
\hline 2007 & 30 & 3,15 & 3 & 2,94 & 3,07 & 3,29 & 3,27 & 3,38 \\
\hline 2010 & 39 & 3,22 & 2,82 & 3,08 & 3,15 & 3,23 & 3,09 & 3,94 \\
\hline 2012 & 27 & 3,51 & 3,16 & 3,62 & 3,38 & 3,52 & 3,54 & 3,87 \\
\hline 2014 & 30 & 3,5 & 3,23 & 3,53 & 3,18 & 3,64 & 3,77 & 3,68 \\
\hline 2016 & 34 & 3,42 & 3,18 & 3,49 & 3,41 & 3,31 & 3,39 & 3,75 \\
\hline 2018 & 47 & 3,15 & 2,71 & 3,21 & 3,06 & 3,05 & 3,23 & 3,63 \\
\hline
\end{tabular}

Kaynak: https://www.lojistikcilerinsesi.biz

Tablo 2 de Türkiye'nin 2018 yılı performans endeksi gösterilmektedir. 2007 yılında Türkiye 30'uncu sırada yer almaktadır. Bu yılda en yüksek performans endeksi gönderilerin zamanında tesliminde görülmektedir. 2012 yılı göz önüne alındığında Türkiye başarı göstererek sırasını 30'dan 27 ye taşıdığı görülmektedir ve birçok alanda da gelişme görülmektedir. Gönderilerin zamanında teslimi 3,38'den 3,94 yükselmiştir. Yakın zamanda 2018 Yılı dikkate 
alındığında ise Türkiye 47'inci sıraya gerilemiş̧tir bazı alanlarda çok değişiklik yaşanmasa da genel olarak Türkiye gerileme yaşamaya devam etmektedir. Daha önce 2016 yılında Türkiye'nin önceki sıralarında yer alan Portekiz, Tayland, Şili, Slovenya, Estonya, Panama, Vietnam, İzlanda, Yunanistan, Umman, Hindistan, Güney Kıbrıs Rum Kesimi ve Endonezya 2018 yılı verilerine göre ise Türkiye'nin önünde yer almaktadır.

\section{Türkiye'de Lojistik Sektörü}

Türkiye lojistik sektörü, bugün 50-60 milyar dolarlık bir lojistik kapasiteye sahiptir ve bu da dünya lojistik hacminin yaklaşık yüzde 1'ini oluşturmaktadır. Türkiye'nin lojistik kapasitesi içerisinde hizmet veren işletmelerin, Lojistik sektörünün Türkiye ekonomisine sağladığı katkı, lojistik değeri yıllık ortalama 6-8 milyar dolardır ve bu da dünya lojistik hacminin yaklaşık binde birini oluşturmaktadır. Lojistik sektörü yaklaşık 400 bin kişiye iş olanağı sağlamaktadır (Özkanlısoy, 2018, s.23).

Lojistiğin sağladığı katkılar arasında milli gelirin yüksek olması, alım gücünün artış göstermesi ve istihdamın artması ile işsizlik oranının azalması, moral ve motivasyonun artışı, eğitim düzeyinin artması, jeo-politik ve jeostratejik önemin artış göstermesi, lojistik üsler, siyasi alandaki güç ve liderlik, stratejik ortaklık, rol modeli ve model ortaklığı, gelirin dağılımındaki adaleti, vergi gelirinin artışı, rekabetin artması, ekonomik alanda büyüme ve kalkınma, dış ticaret hacminin artışı, yabancı sermaye artması bulunmaktadır (Uğur, 2019, s.42).

Türkiye' de ekonomik faaliyetlerin gerçekleştirilmesinde önemli bir rol oynayan lojistik hizmet, ithalat ve ihracat süreçlerine etki etmektedir. Bu kapsamda taşımacılık, lojistik faaliyetler içinde önemli bir paya sahiptir. 2016 y1lında dış ticarette meydana gelen mal hareketlerinin taşıma modlarına göre dağılımın incelendiğinde, ilk sırada yüzde 58,27 payla denizyolunun, onu takiben yüzde $23,18^{\prime}$ lik bir payla karayolunun, yüzde $11,94^{\prime}$ le havayolunun ve yüzde 0,61'le demiryolunun geldiği görülmektedir. 2017 yılında ise, ihracat 157,055 milyar dolar, ithalat 233,791 milyar dolar tutarında gerçekleşmiş ve toplam diş ticaretin yüzde 58,305'i denizyoluyla, yüzde 22,67'si karayoluyla, yüzde 12,405'i havayoluyla ve yüzde 0,45'i demiryoluyla gerçekleşmiştir (Özkanlısoy, 2018, s.23). 
Türkiye'de 2016 ve 2018 yılları arasında kriterlere bakarak karşılaştırma yapilırsa;

- Gümrük kriterinde 2016 yılında Türkiye 3,18 puanlamayla 36. sırada yer alırken 2018 yılında 2,71 puanla 58. sıraya düşmüştür,

- Altyapı kriterinde 2016 yılında ise 3,49 puanla 31. Sirada bulunurken 2018 yilında 3,21 puanla 33. Sıraya düşmüştür,

- Uluslararası Sevkiyat kriterinde 2016 yilında, 3,41 puanla 35. sirada yer alırken 2018 yilında 3,06 puanla 53. siraya düşmüştür,

- Lojistik Hizmetlerin Kalitesi kriterinde 2016 yilında 3,31 puanla 36. s1radayken 2018 yılında 3,05 puanla 51. sıraya düşmüştür,

- Gönderilerin Takibi ve İzlenebilirliği kriterinde 2016 yılında 3,39 puanla 43. Sırada bulunurken 2018 yılında 3,23 puanla 42. sıraya yükseliş olmuştur,

- Gönderilerin Zamanında Teslimi kriterinde 2016 yılında 3,75 puanla 40. Sırada yer alırken 2018 yılında 3,63 puanla 44. sıraya düşmüştür (www.lojistikcilerinsesi.biz).

\section{Lojistik Sektöründe Meydana Gelen Gelişmeler}

Nüfustaki artış sürekli artan ihtiyaçların ve endüstrileşmenin hızla büyümesi ile beraber 1950 yılı ile birlikte çok büyük gelişmeler gösteren bu sektör; değişmelere uyum sağlamaya çalışırken teknolojik gelişmelerin öne sürdüğü kaynakları kullanabilmek için büyük yatırım yapmaktadır. "Doğru ürünün, doğru yerde, doğru zamanda ve doğru bir maliyetle" teslim edilmesi amacına hizmet eden yeni teknolojiler, lojistik sektörünü sektörü daha da ileri seviyelere taşımaktadır.

Lojistik sektörünün gelişmesi ile dış ticaret kapsamında Türk firmalarının rekabet gücüne ve istihdam sorununun çözümüne de önemli katkıda bulunmaktadır. Eksikliklerin giderilmesi ile lojistik sektörünün Türk ekonomisine katkısı da önemli bir düzeyde olacaktır(Bulut, 2007, s.109-110).

\section{Lojistik Sektörünün Ekonomiye Katkısı}

Dünya'daki toplam GDP'nin (Gayri Safi Yurtiçi Hâsıla) yaklaşık \% 15'i Lojistik sektöründen meydana gelmektedir. Türkiye'deki lojistik sektörünün büyümesi ülke büyümesiyle paralellik göstermektedir (Akan, 2015, s.5). 
Lojistik sektörü, bu alandaki verilen kararların ülkenin ticaretinden dolayı önemli bir yere sahip olması, bu sektörün Türkiye'de iş yaratma ve büyüme potansiyelinden dolayı öne çıkan sektörlerden birisi olmasından ve hızla ilerlemesinden dolayı dünya ekonomisi için olduğu kadar, Türkiye ekonomisi için de büyük önem arz etmektedir. Ülkemizin Avrupa, Asya ve Afrika kıtaları arasındaki coğrafik ve stratejik konumundan dolayı, lojistik sektörünün değeri her geçen gün artış göstermektedir (Baki, 2004, s.43).

Lojistik ve ülke ekonomisinde ilk olarak; sektöründeki iş hacmi ülke ekonomisinden etkilenmektedir. Ekonomi de canlılık görüldügü zaman lojistik iş olanakları artmakta ve durağan olması halinde lojistik faaliyetlerine olan talepte düşüş görülmektedir (Thuermer, 2003, s.26).

\section{Yükseköğretim Kurumunda Lojistik Programlarının Durumu}

Türkiye'de ön lisans eğitimi veren lojistik programları sürekli artış göstermektedir. Türkiye'de 2011 yllında ön lisans programında sadece Anadolu Üniversitesi Açlk Öğretim Fakültesi'nde lojistik programı yer alırken, şuan örgün eğitim veren 52 meslek yüksekokulunda "Lojistik" bölümü bulunmaktadır. Bu bölüm ve meslek yüksekokullarında toplamda 4460 öğrenciye eğitim verilmektedir. 2015 yılı verilerine göre de, Türkiye'de toplam 70 farklı üniversitede lojistik programlarında eğitim verilmektedir ve yaklaşık olarak 10 bin kadar öğrenci (9647) kontenjanı bulunmaktadır. 2011-2015 yılları arasında üniversitelerde lojistik programlarına olan ilgi her geçen gün artış göstermektedir. Sektördeki büyümede lojistik eğitimine olan ilginin giderek artmasına katkı sağlamıştır. Eğitim veren meslek yüksekokullarındaki lojistik programlarında elde edilen sonuçlara bakılırsa lojistik sektörü için yeterli ve gerekli düzeyde bireyler yetiştirmek için yeterli düzeyde olmadığı görülmektedir (Çıkmak, 2016, s.4).

2019 yılında ise Türkiye'de 35 Vakıf üniversitesinde lojistik bölümü bulunmaktadır. Ayrıca, Devlet Üniversitelerinde 52 ön lisans lojistik programı, 33 lojistik lisans programı ve 41 ön lisans ikinci öğretim programında eğitim verilmektedir. 
Lojistik Bölümünü Tercih Eden Öğrencilerin Lojistik Sektöründen Beklentileri - Karamanoğlu Mehmetbey Üniversitesi Örneği

Tablo 3. Türkiye'de eğitim veren önlisans lojistik programlan

\begin{tabular}{|c|c|c|}
\hline BULUNDUĞU YER & ÜNIVERSITE & KONTENJAN \\
\hline Adiyaman & Adıyaman Üniversitesi & 35 \\
\hline Artvin & Artvin Çoruh Üniversite & 40 \\
\hline Erzurum & Atatürk Üniversitesi & 30 \\
\hline Aydın & Adnan Menderes Üniversitesi & 265 \\
\hline Balıkesir & Balıkesir Üniversitesi & 100 \\
\hline Bayburt & Bayburt Üniversitesi & 60 \\
\hline Bitlis & Eren Üniversitesi & 40 \\
\hline Bolu & Abant İzzet Baysal Üniversitesi & 60 \\
\hline Burdur & M. Akif Ersoy Üniversitesi & 40 \\
\hline Bursa & Uludağ Üniversitesi & 120 \\
\hline Çanakkale & 18 Mart Üniversitesi & 145 \\
\hline Düzce & Düzce Üniversitesi & 35 \\
\hline Erzincan & Binali Yıldırım Üniversitesi & 55 \\
\hline Eskişehir & Eskişehir Teknik Üniversitesi & 65 \\
\hline Gaziantep & Gaziantep Üniversitesi & 155 \\
\hline Gümüşhane & Gümüşhane Üniversitesi & 20 \\
\hline Hakkâri & Hakkâri Üniversitesi & 30 \\
\hline Hatay & Mustafa Kemal Üniversitesi & 170 \\
\hline Çorum & Hitit Üniversitesi & 30 \\
\hline Iğdır & Iğdır Üniversitesi & 35 \\
\hline Isparta & Uygulamalı Bilimler Üniversitesi & 270 \\
\hline Hatay & İskenderun Teknik Üniversitesi & 45 \\
\hline Kars & Kafkas Üniversitesi & 45 \\
\hline Kahramanmaraş & Sütçü İmam Üniversitesi & 135 \\
\hline Trabzon & Karadeniz Teknik Üniversitesi & 50 \\
\hline Karaman & Karamanoğlu Mehmetbey Üniversitesi & 45 \\
\hline Kastamonu & Kastamonu Üniversitesi & 35 \\
\hline Kayseri & Kayseri Üniversitesi & 50 \\
\hline Kurklareli & Kırklareli Üniversitesi & 85 \\
\hline Kurşehir & Kırşehir Üniversitesi & 35 \\
\hline Kocaeli & Kocaeli Üniversitesi & 70 \\
\hline Kütahya & Dumlupınar Üniversitesi & 195 \\
\hline Manisa & Celal Bayar Üniversitesi & 90 \\
\hline Mersin & Mersin Üniversitesi & 140 \\
\hline Muğla & Sttk1 Koçman Üniversitesi & 50 \\
\hline Nevşehir & Hacı Bektaş Veli Üniversitesi & 45 \\
\hline Samsun & On Dokuz Mayıs Üniversitesi & 110 \\
\hline Ordu & Ordu Üniversitesi & 95 \\
\hline Denizli & Pamukkale Üniversitesi & 85 \\
\hline Rize & Recep Tayyip Erdoğan Üniversitesi & 55 \\
\hline Sakarya & Uygulamalı Bilimler Üniversitesi & 110 \\
\hline Konya & Selçuk Üniversitesi & 275 \\
\hline Sinop & Sinop Üniversitesi & 85 \\
\hline Sivas & Cumhuriyet Üniversitesi & 30 \\
\hline Şırnak & Şırnak Üniversitesi & 30 \\
\hline
\end{tabular}




\begin{tabular}{lll}
\hline Tekirdağ & Namk Kemal Üniversitesi & 180 \\
\hline Tokat & Gaziosmanpaşa Üniversitesi & 40 \\
\hline Edirne & Trakya Üniversitesi & 225 \\
\hline Uşak & Uşak Üniversitesi & 60 \\
\hline Yalova & Yalova Üniversitesi & 60 \\
\hline Zonguldak & Bülent Ecevit Üniversitesi & 10 \\
\hline & & TOPLAM: 4460 konten- \\
& & jan (öğrenci kapasitesi ) \\
\hline
\end{tabular}

Kaynak: https://www.tabanpuanlari.xyz

Tablo 3'te Türkiye'de ön lisans programlarında eğitim veren devlet üniversiteleri ve bu üniversitelerin öğrenci kapasitesi, kontenjanı gösterilmektedir. Türkiye'de 52 ön lisans programlarında lojistik eğitimi verilmektedir. Bu üniversitelerde en fazla lojistik bölümü kontenjanına sahip üniversite Köşk Meslek Yüksekokulunda normal öğretimde 90 kişilik kontenjan, ikinci öğretimde 50 kişilik kontenjan, Nazilli Meslek Yüksekokulu normal öğretim de 70 kişilik kontenjan ve ikinci öğretimde ise 55 kişilik kontenjanla toplamda 265 öğrenci kapasitesi ile Aydın Adnan Menderes Üniversitesidir. Tabloya göre bir sonraki en fazla öğrenci kapasitesine sahip olan üniversite ise Edirne Sosyal Bilimler Meslek Yüksekokulun normal öğretimde 70 kişilik kontenjan, ikinci öğretimde 45 kişilik kontenjan, Havsa Meslek Yüksekokulunda 70 kişilik kontenjan ve İpsala Meslek Yüksekokulunda 40 kişilik kontenjan ile toplamda 225 öğrenci kapasitesine sahip ikinci üniversitedir. En düşük öğrenci kapasitesine sahip üniversite ise 10 kişilik kontenjan ile Zonguldak Bülent Ecevit Üniversitesidir. Toplamda Türkiye'de 52 üniversitede toplam 4460 öğrenci kapasitesi ile eğitim verilmektedir.

\section{Lojistik Sektöründe İstihdam Olanakları}

Türkiye Avrupa, Asya ve Afrika kıtalarının arasında uluslararası alanda lojistik üs olmak için çalışmalar yapmaktadır. Bu sebepten dolayı da lojistik sektörü iyi yetişmiş çok sayıda nitelikli elemana ve insan gücüne ihtiyaç duymaktadır. Lojistik sektörünün öneminin her geçen gün artmasından dolay1 kalifiyeli eleman arayışında artış görünmektedir. Lojistik sektöründe en çok istihdama ihtiyaç duyulan bölüm karayolu operasyon ve depo yönetimi bölümleridir (http://www.lojistikhatti.com/). Uluslararası Nakliyeciler Derneği Başkanı Çetin Nuhoğlu Türkiye'de lojistik sektöründe yaklaşık bir milyon ki- 
şinin istihdamının sağlandığını belirtmiş̧tir (www.hurriyet.com.tr/). 2023 yılında da lojistik sektöründe 1,5 milyon kişinin istihdam edilmesi beklenmektedir.

Türk lojistik sektöründe istihdamın sağlanması için bazı devlet destek programları bulunmaktadır. Ekonomik politikalar çerçevesinde kanunlar kapsamında sağlanan destekler, kalkınmada öncelikli yörelerde istihdam teşviki, işveren sigorta prim indirimi desteği, gençlerin ve kadınların istihdamını arttırma desteği, ilave istihdam teşviki, işsizlik ödeneği alanların istihdamının teşviki, araştırma ve geliştirme (AR-GE) teşviki gibi desteklerle istihdama katkı sağlanmaktadır (Koban, 2013, s.38-39).

\section{Lojistik Sektöründe Kariyer Planlaması}

Kariyer basamaklarını doğru şekilde çıkabilmek ve basamakları belli bir süreçte hangi zaman dilimini kullanarak neyin nasıl yapılması gerektiğine karar vererek kariyer planlaması olarak ifade edilir (Schreuder ve Theron, 1999, s.4)

Öğrenciler için kariyer genel olarak iş ve mesleği tanımlamakta ve ailesel veya kişisel beklentilerden etkilenmektedir (Noe, 1999). Kusluvan (2000) çalışmasında Türkiye'de lisans düzeyinde eğitim alan öğrencilerin yüzde 42.75'i sektörde kariyer yapmak istemektedir. Koyuncu (2011) çalışmasında ikinci sınıf, üçüncü sınıf ve dördüncü sınıfta okuyan öğrencilerin, erkeklere göre kadınların okulun başındaki öğrencilerin okulun sonlarındaki öğrencilere kıyasla sektördeki daha az deneyimli öğrencilerin daha fazla deneyimli öğrencilere kıyasla sektörde kariyer yapmak istediklerini ortaya koymuştur (Çarıkçı ve Morçin, 2014, s.71).

Okullarda uygulamaların sınırlı olması nedeniyle stajın, öğrencilerin okulda öğrendiklerini pratiğe aktarmada yardım etmektedir. Staj uygulamaları öğrencilerin sektörü daha iyi anlamalarına katkıda bulunmaktadır ve işletmelerde uyum sağlamayı kolaylaştırmaktadır. Stajını başarılı bir şekilde bitiren öğrenciler ilerde kariyer yapmak istemektedirler. Öğrenciler mezun olduktan sonra hemen iş bulmaları ve kariyer planlamalarında başarılı için okullarda öğrencilere verilen eğitim kadar öğrencilerin ilgi alanlarına kişisel yetenek ve becerilerine uygun bir kariyer yapmak istediklerini belirtmektedir. Bu amaca ulaşmak için ise iyi bir kariyer planı geliştirmek istedikleri açıklanmıştır (Gürdoğan ve Atabey, 2015, s.96). 


\section{Yöntem}

\section{Araştırmanın Önemi}

Lojistik sektörü hakkında günümüzde çok bilgi sahibi olunmadığ 1 için sektörün iş tercihi konusunda zorluk yaşanmaktadır. Bu çalışma, lojistik bölümünde lisans ve önlisans düzeyinde eğitim gören öğrencilerin sektör hakkında beklentilerini araştırıp ölçerek sektör hakkında bilgi sahibi olmalarına olanak sağlamaktadır. Öğrencilerin kariyer planlamaları konusunda yardımcı olması ve öğretim elemanlarının öğrencileri mesleğe yönlendirmeleri konusunda önerilerde bulunma açısından çalışma önemli katkılar sunmaktadir.

\section{Veri Toplama Araçları}

Yapılan araştırmada bulunan bilgiler kapsamında anket tekniği uygulanmıştır. Anket tekniği araştırmaciya bilgilere kolay erişim imkanı sunarak ve daha geniş bir gruba ulaşmayı sağlamaktadır (Balcı, 2001, s.179; Baş, 2001, s.11).

Araştırmada kullanılan anket iki bölümden oluşmaktadır. İlk bölüm ankete katılan öğrencilerin cinsiyeti, yaşı, eğitim durumu, kaçıncı sınıf oldukları lojistik bölümünü seçme nedenleri, lojistik sektörü ile ilgili takip ettikleri süreli yayın olup olmadığı, çalışma durumu, çalışlıyorsa hangi bölümde çalıştıkları ve ailelerinde lojistik sektöründe çalışan olup olmadıklarını içeren demografik özellikleri sorulmuştur. İkinci bölümde 5'li likert ölçekli sorular bulunmaktadır. Ankette lojistik sektörüne ilişkin görüşler olan 6 soru, lojistik eğitimine ilişkin görüşlerin bulunduğu 5 soru, lojistik sektöründe kariyere ilişkin görüşlerin bulunduğu 5 soru, çevre etkisine ilişkin görüşlerin bulunduğu 3 soru ve çalışma niyetinin bulunduğu 7 soru ile toplamda 26 soru bulunmaktadır.

\section{Araştırmanın Yöntemi ve Ölçekleri}

Araştırmanın ana kütlesini, Karamanoğlu Mehmetbey Üniversitesi Lojistik programını okuyan veya programdan mezun olan ön lisans/lisans öğrencileri oluşturmaktadır. Lisans programına öğrenci alımı 2018 güz döneminde, ön 
lisans programına öğrenci alımı 2013 güz döneminde alınmaya başlandığından dolayı, 2019 yılı ön lisans/lisans devam eden öğrenci sayısı toplam 93, ön lisans programından geçmiş yıllarda toplam 242 mezun öğrenci bulunmaktadır. Yapılan anket sayısında okuyan ve mezun olan öğrenci sayısına bakıldığı takdirde, örneklem sayısının yeterli olduğu görülmektedir. Eksik veriler ise mezun olan bazı öğrencilerin iletişim adresleri değişmesinden ve geri dönüş yapmamaları nedeniyle kaynaklanmaktadır. Dolayısı ile analizlere konu olan anket formu sayısı 232 adettir.

İki bölümden oluşan anketin birinci bölümü katılımcının demografik özelliklerini (yaş, cinsiyet, eğitim seviyesi ve sınıfı, çalışma durumu vb.) göstermektedir. İkinci bölümde, araştırma değişkenleri (lojistik sektörü, alınan eğitim, çevre etkisi ve kariyer olanaklarının lojistik sektöründe çalışma niyetine etkisi) ölçen önermeler yer almaktadır.

Anketin diğer bölümünde yer alan sorular 5'li Likert tipi ölçeği (1=Kesinlikle Katılmıyorum, 2=Katılmıyorum, 3=Kararsızım, 4=Katılıyorum, 5=Kesinlikle Katılıyorum) ile ölçümlenmiştir.

Düzenlenen modeli analizi için yapısal eşitlik modeli (YEM) kullanılmıştır. Yapısal eşitlik modellemesi ile analiz edildiğinde, numune kapasitesi en az 200-500 arasında olmalıdır (Mobius, 2003; Dursun ve Kocagöz, 2010). Bu çalışmada kullanılan örneklem büyüklüğü 232 olduğundan, örneklem miktarı yeterlidir. Yapısal eşitlik modellemesi ve analizi, AMOS programı kullanılarak ve diğer analizler SPSS programı kullanılarak yapılmıştır.

Bu çalışmada; kariyer olanakları ölçeği Pehlivan (2018) ve Orhan (2015) yılında yapmış oldukları çalışmalarından, lojistik sektörü, çalışma niyeti, eğitim, çevre etkisi ölçekleri ise Düzgün (2015), Çavuş vd. (2015), Üzümcü vd. (2015), Sarışık (2015), Türkay vd. (2015) yılında yapmış oldukları çalışmalarindan yararlanılmıştır.

\section{Araştırmanın Modeli ve Hipotezleri}

Bu çalışmanın amacı, öğrencilerin lojistik sektörüne bakışı, aldıkları eğitimin, çevre etkisi ve lojistik sektöründe kariyer olanaklarının, lojistik sektöründe çalışma niyetine etkisi üzerine ilişkisini, Şekil-1'de sunulan çalışma modeli ile araştırmaktır. Bu bağlamda, araştırma aşağıdaki hipotez çerçevesinde yapılmiştır. 


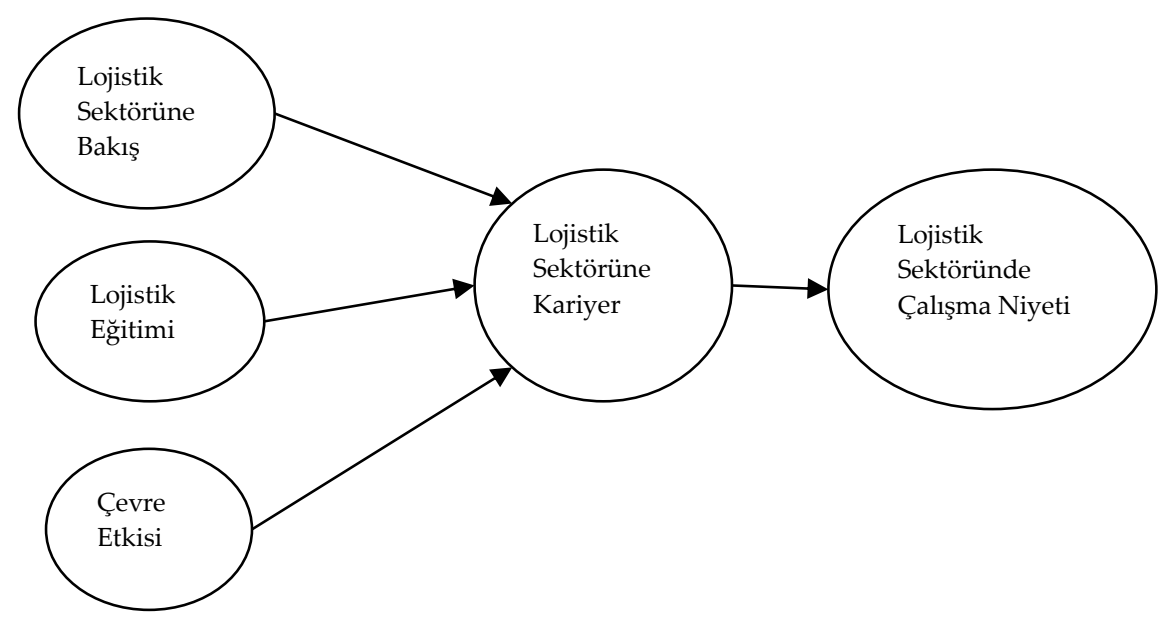

Şekil 1. Araştırmanın kavramsal modeli

- H1: Öğrencilerin lojistik sektörüne bakışı lojistik sektöründe kariyer yapma isteği arasında olumlu ilişki vardır.

Sektörde mesleki değerler; para kazanma, ün kazanma, düzenli bir hayata sahip olma, başkalarını yönetme, tekdüze olmayan bir hayat yasama, rekabet etme, yaratıclığını geliştirme, başkalarına yardım etme, yeteneklerini geliştirme, bağımsız olma gibi durumlar sektörde yaşanan zorluklar sektörün kariyer seçimine etki ettiği görülmektedir (Kuzgun, 1989, s.5; Pehlivan, 2008, s.53).

Dinçer vd. çalışmasında İstanbul Üniversitesi ile Gümüşhane Üniversitesi meslek yüksekokullarında eğitim gören öğrencilerin kariyer hakkında yaptıkları plan ve bu planı ortaya çıarmak için ve sektör hakkında düşüncelerini ve bakış açılarını bir anket uygulamasıyla orta koymaya çalışmıştır. Dinçer' in yaptığı çalışma sonucunda ise sektördeki imkânlar ve olanakların kariyerlerini etkilediği ve sektörde kariyer yaşamlarına devam etmek istedikleri ve bu sektörde uzun zaman çalışmak istediklerinin sonucuna varılmıştır. Bu öğrenciler üst düzey pozisyonlarda çalışmak istediklerini de belirttiklerini belirtmişlerdir. Ayrıca çalışmaya katılan öğrencilerin sektör hakkında olumlu farklılıklar sergiledikleri tespit edilmiştir (Aksu, 2017, s.10).

- H2: Öğrencilerin okulda aldıkları eğitimin lojistik sektöründe kariyer yapma isteği arasında olumlu ilişki vardır. 
Wu vd. (2012) çalışmasında yüksekokulların sorunları üzerinde yoğunlaşarak bu sorunlar üzerinde çözüm önerilerinde bulunarak eğitimin kalitesini iyileştirmeyi ve bu yönde öğretim elemanların bilinçlendirip gelişmelerini sağlamayı amaçlamıştır. Bu çalışmanın sonucunda da düzenli bir şekilde kurallara uyulmak eğitimi daha iyi bir hale getirmek için önerilerde bulunarak bir analiz ve değerlendirme yapılması gerektiğini vurgulamıştır. İyi bir eğitim ortamı öğrencilerin başarılarda artışı neden olacaktır. İyi bir eğitim ortamında öğrenimlerine devam eden öğrencilerde kariyer alanlarında ilerlemelerine katkı sağlayacaktır (Baki, 2017, s.11).

Pekel (2016) çalışmasında öğrenciler hangi eğitim kademesinde olurlarsa okuldaki iyi yaşamları ve okul yaşamlarında eğitimlerinde iyi olmaları öğrencileri geleceğe destekleyici niteliktedir sonucuna varmıştır. Yapılan araştırmalarda okuldaki eğitim öğretim kalitesi akademik yönde başarıyı olumlu yönde etkilemektedir. Öğrencilerin aldıkları eğitimin kalitesi hem akademik yönden olumlu etkilerken kariyer ve öz yeterliliklerini de olumlu yönde etkilemektedir (Şimşir, 2018, s.166).

- H3: Öğrencilerin çevre etkisinin lojistik sektöründe kariyer yapma isteği arasında olumlu ilişki vardır.

Tuncer (2011) yaptığı bir çalışmanın sonucunda öğrencilerin kariyer ve gelecek beklentilerinde cinsiyetin önemli etkileri olduğu sonucuna varmıştır. Çalışmanın sonucunda kadın öğrencilerin yararına bir şekilde farklılık olduğunu belirtmiştir. Ayrıca öğrencilerin kardeş sayıları arttıkça gelecek beklentileri ve kariyer beklentilerinde anlamlı fark bulunmuştur. 3 ile 4 kardeşe sahip olan öğrenciler ile 5 ve üzeri kardeşe sahip öğrenciler arasındaki fark bulunmaktadır. Ayrıca öğrencilerin gelecek ve kariyer beklentilerde teknoloji ve küreselleşmeye bağlı belirsizliklerin de kariyer ve gelecek beklentilerini etkilediği görülmüştür (Aksu, 2017, s.11).

Öz yeterlilikleri yüksek olanlarla kendi başarıları hakkında şüphe duyan öğrenciler kıyaslandığında derse katılma oranları hazırlıklı bulunmaları daha kararlı bir şekilde ve daha fazla çalıştıkları gözlemlenmektedir. Bütün bunların öğretim elemanlarının ve çevredeki diğer başarılı öğrencilerin diğer öğrencinin başarmasında ve kariyerine odaklanmasında önemli katkıları vardır (Bandura, 1997; Pajares, vd. 2001; Şimşir, 2018, s.166). 
Anne Roe 1956 senesinde yayınlamış olduğu "Meleklerin Psikolojisi" adlı kitabında kariyeri kişi psikolojisi üzerinde ele alarak kişinin kariyer düşüncesini ve seçimini Maslow'un ihtiyaçlar hiyerarşisi ile bağlamıştır. Anne Roe bu kuramına kişilik gelişimi olarak adlandırmaktadır. Bu kuram da çevre, ihtiyaçların gelişmesi, kişiliğin farklılık göstermesi kariyer seçiminde etkili olduğunu vurgulamıştır ( Pehlivan, 2008, s.44).

Riegel ve Dallas (1998) yaptıkları çalışmada insanların kariyerlerini seçerken ilgilerinin yeteneklerinin ve diğer faktörlerin yanında ekonomik ve sosyal kültürel alanda faktörlerde etkili olmaktadır. Farmer (1987) yaptığı çalışmasında insanların kariyerlerini seçerken kişiliklerinin de etkili olduğunu vurgulamıştır. Bu kuramında Farmer kişinin geçmiş yaşantısı, cinsiyeti ve yaş gibi unsurlarında kariyer seçiminde etkisi olduğunu vurgulamıştır (Pehlivan, 2008, s.51).

- H4: Öğrencilerin lojistik sektöründe kariyer yapma isteği ile lojistik sektöründe çalışma niyeti arasında olumlu ilişki vardır.

Öğrenciler genel olarak kariyer seçimlerinde baktıkları nokta maaş, çalışma koşulları, işin kendilerine uygun olup olmadıklarıdır. Çevresel etkiler olan kişilik, teknoloji, sosyal çevre, gibi etkenler öğrencilerin çalışma niyetlerini etkilemektedir.

Genel olarak yapılan çalışmalar sektörde kariyer yapan kişilerin işlerine saygınlığının düşük olduğu belirtilmektedir. Çalışma sürelerinin uzun olması, verilen ücretlerin yeterli miktarda olmaması, iş güvenliğinin yeterli olmadığını düşünen kariyerlerinde ilerleyen kişilerin çalışma niyetlerini etkilemektedir. Eğitim alan öğrencilere yapılan çalışmalarda da kariyer planlaması yaparken çalışma koşulları ve ücretin düşük olmasının, saygınlık görülmemesinin kariyer yapmak ve ayrıca ilerde bu sektörde çalışma niyetlerini etkiledikleri görülmektedir. Sosyal yaşantı ve aile yaşam standartlarının az olması çalışma niyetinin etkilemektedir (Duman, vd. 2006, s.53).

\section{Araştırmanın Kısıtları}

Çalışma sadece Karaman ilinde yapılmasından dolayı, tüm üniversite öğrencileri ve mezunlarını yansıtmamaktadır. Ayrıca, anketlerde öznel bir değerlendirme yapıldığından, istenilen durumdan ziyade olması düşünülen durumu ortaya çıkma olasılığı nedeniyle ölçüm hataları olabilmektedir. 


\section{Bulgular}

Bu bölümde, öğrencilerin demografik bilgileri ilk önce ele alınmıştır. Daha sonra güvenilirlik ve doğrulayıc faktör analizine ilişkin sonuçlar sunulmuştur. Son olarak, araştırma hipotezini doğrulamak için yapısal eşitlik modelleme analizinin sonuçları tartışılmıştır.

Demografik Özellikler

Tablo 4. Katılımcılarn demografik özellikleri

\begin{tabular}{|c|c|c|c|}
\hline & & Frekans & Yüzde \% \\
\hline \multirow[t]{3}{*}{ Cinsiyet } & Kadın & 93 & 40.1 \\
\hline & Erkek & 139 & 59.9 \\
\hline & Toplam & 232 & 100 \\
\hline \multirow[t]{4}{*}{ Eğitim } & Önlisans & 72 & 31 \\
\hline & Lisans & 21 & 0.09 \\
\hline & Mezun & 139 & 60 \\
\hline & Toplam & 232 & 100 \\
\hline \multirow[t]{5}{*}{ Sinif } & 1 & 52 & 56 \\
\hline & 2 & 41 & 44 \\
\hline & 3 & 0 & 0 \\
\hline & 4 & 0 & 0 \\
\hline & Toplam & 93 & 100 \\
\hline \multirow[t]{5}{*}{ Lojistik Bölümü Seçme Nedeni } & Kendim İsteyerek & 87 & 37.5 \\
\hline & Çevremin etkisi & 82 & 35.3 \\
\hline & Puan & 60 & 25.9 \\
\hline & Diğer & 3 & 1.3 \\
\hline & Toplam & 232 & 100 \\
\hline \multirow[t]{2}{*}{ Süreli Yayın } & Var & 62 & 26.7 \\
\hline & Yok & 170 & 73.3 \\
\hline \multirow[t]{4}{*}{ Çalışma Durumu } & Kısmi süreli & 59 & 25.4 \\
\hline & Tam Zamanlı & 50 & 21.6 \\
\hline & Çalışmiyorum & 123 & 53 \\
\hline & Toplam & 232 & 100 \\
\hline \multirow[t]{4}{*}{ Yaş } & 18-21 & 90 & 38.8 \\
\hline & $22-25$ & 81 & 34.9 \\
\hline & 25-Üstü & 61 & 26.3 \\
\hline & Toplam & 232 & 100 \\
\hline
\end{tabular}

Katılımcların (öğrencilerin) demografik özellikleri Tablo-4'de yer almaktadır. Katılımcıların büyük bir oranda erkeklerden oluştuğu (\%59.9) ve yine yüksek bir oranının (\%60) mezun olduğu ve \%28.8'inin 18-21 yaş aralığında bulunduğu görülmektedir.

Tablo-4'te katılımcıların lojistik bölümünü seçme nedenlerine bakıldığında en fazla oran \% 37.5 ile kendisinin isteyerek seçtiği tespit edilmiş, fakat 
bunun yanında yine sektörün önemli etkisinin neticesi olarak çevre yönlendirmesi ise \%35.3 olduğu görülmektedir. Bu oranlara bakıldığında lojistik bölümünün bilinçli olarak seçildiği ve öneminden dolayı çevre tarafından yönlendirildiği tespit edilmiştir. Bunun yanında öğrencilerin mesleki olarak kendini geliştirme çabası olarak süreli yayın takibi yapmaları \%26.7 oran ile oldukça düşük çıkmıştır.

Çalışmada, veri toplama aracı olarak anket yöntemi kullanılmıştır. Anket formunda yer alacak ölçeklerin oluşturulmasında, kapsamlı bir literatür incelemesi yürütülmüsştür. Önceki çalışmalarda kullanılan maddelerden yararlanılmıştır. Ölçeklerin güvenirliğini belirlemek için Cronbach alfa katsayısı hesaplanmıştır. Özdamar'a (1999) göre Cronbach Alfa katsayısi; 0.40-0.60 arasında olursa güvenilirdir, 0.60-0.80 arasında olması oldukça güvenilirdir, eğer $0.80-1.00$ arasında olursa yüksek derecede güvenilir olduğu anlamına gelmektedir.

Geliştirilen ve bu çalışmada kullanılan tüm ölçeklerin geçerlik ve güvenilirlikleri, doğrulayıc faktör analizleri yardımıyla değerlendirilmiştir. Doğrulayıcı faktör analizi sonucu; lojistik sektörü altında yer alan 6 değişkenden bir madde, lojistik eğitimi altında yer alan 5 değişkenden iki madde, lojistik kariyer altında yer alan 5 değişkenden bir madde, çalışma niyeti altında yer alan 7 değişkenden bir madde model uyum değerlerinin kabul edilebilir düzeyde olmadıkları neticesinde çıkarılmıştır. Analiz sonucunda, önerilen modifikasyonlar yapılmış ve modifikasyon sonrası model uyum değerleri Tablo-5'de, araştırma modelinin birleşim geçerliliğini ölçmek için AVE ve CR değerleri Tablo-6'da, yapısal eşitlik analizi ile araştırma modeli Şekil-2'de gösterilmiştir.

Tablo 5. Yapısal model analizinde uyum iyiliği indeksleri ve modele ait değerler

\begin{tabular}{|c|c|c|c|}
\hline Uyum Ölçüleri ve Sınırları & A racturma Madoli & Ölçekler & Cronbach Alpha \\
\hline Yeterli & Araşumina iviodent & & Katsayısı \\
\hline $0.90 \leq$ NFI $\leq 1.00$ & 0,913 & Lojistik Sektörü & 0,917 \\
\hline $0.95 \leq \mathrm{CFI} \leq 1.00$ & 0,945 & Lojistik Eğitimi & 0,816 \\
\hline $0.90 \leq \mathrm{GFI} \leq 1.00$ & 0,840 & Çevre Etkisi & 0,835 \\
\hline $0.10>$ RMSEA $>0.00$ & 0,81 & Lojistik Kariyer & 0,859 \\
\hline $\mathrm{x} 2 / \mathrm{df}<3.00$ & 2,530 & Çalışma Niyeti & 0,961 \\
\hline
\end{tabular}

Kaynak: Schermelleh-Engel vd. (2003) ve Tan vd. (2007). 
Tablo 6. AVE ve CR Değerleri

\begin{tabular}{|c|c|c|c|c|c|}
\hline \multicolumn{3}{|c|}{ Standardized Regression Weights } & Estimate & AVE & $\mathrm{CR}$ \\
\hline Lojistiksektörü5 & $<--$ & LojistikSektöra & 0,744 & \multirow{5}{*}{0,68} & \multirow{5}{*}{0,91} \\
\hline Lojistiksektörü4 & $<--$ & LojistikSektöra & 0,811 & & \\
\hline Lojistiksektörü3 & $<--$ & LojistikSektöra & 0,79 & & \\
\hline Lojistiksektörü2 & $<--$ & LojistikSektöra & 0,884 & & \\
\hline Lojistiksektörü1 & $<--$ & LojistikSektöra & 0,88 & & \\
\hline Lojistikeğitimi9 & $<--$ & LojistikEğitima & 0,804 & \multirow{3}{*}{0,61} & \multirow{3}{*}{0,72} \\
\hline Lojistikeğitimi8 & $<--$ & LojistikEğitima & 0,825 & & \\
\hline Lojistikeğitimi7 & $<--$ & LojistikEğitima & 0,717 & & \\
\hline Çevreetkisi19 & $<--$ & ÇevreEtkisia & 0,851 & \multirow{3}{*}{0,58} & \multirow{3}{*}{0,70} \\
\hline Çevreetkisi18 & $<--$ & ÇevreEtkisia & 0,669 & & \\
\hline Çevreetkisi17 & $<--$ & ÇevreEtkisia & 0,761 & & \\
\hline Lojistikkariyer12 & $<--$ & LojistikKariyera & 0,757 & \multirow{4}{*}{0,59} & \multirow{4}{*}{0,85} \\
\hline Lojistikkariyer13 & $<--$ & LojistikKariyera & 0,728 & & \\
\hline Lojistikkariyer14 & $<--$ & LojistikKariyera & 0,746 & & \\
\hline Lojistikkariyer15 & $<--$ & LojistikKariyera & 0,843 & & \\
\hline Çalışmaniyeti20 & $<--$ & ÇalışmaNiyeta & 0,909 & \multirow{6}{*}{0,80} & \multirow{6}{*}{0,96} \\
\hline Çalışmaniyeti21 & $<--$ & ÇalışmaNiyeta & 0,949 & & \\
\hline Çalışmaniyeti22 & $<--$ & ÇalışmaNiyeta & 0,957 & & \\
\hline Çalışmaniyeti23 & $<--$ & ÇalışmaNiyeta & 0,953 & & \\
\hline Çalışmaniyeti24 & $<--$ & ÇalışmaNiyeta & 0,797 & & \\
\hline Çalışmaniyeti25 & $<--$ & ÇalışmaNiyeta & 0,78 & & \\
\hline
\end{tabular}

AVE değerinin $0,5^{\prime}$ ten büyük olması beklenmektedir. CR değerinin 0,7'den büyük olması beklenmektedir. Tablo- 6 ' da bu sonuçlar tüm faktörlerin yüksek güvenilirliğe sahip olduğunu (CR değerleri. 70'in üzerindedir) göstermektedir. Faktörlere ait AVE değerinin CR değerlerinden düşük olması ve AVE değerlerinin $(0,5)$ üzerinde olması faktörlerin birleşim geçerliliğine sahip olduğuna işaret etmektedir.

$\mathrm{AVE}=\sum \lambda^{2} / \mathrm{n}$ (Faktör Yüklerinin karelerinin toplamı/Madde sayısı)

$\mathrm{CR}=\left(\sum \lambda\right) 2 /\left(\left(\sum \lambda\right) 2+\left(\sum 1-\lambda 2\right)\right)$ Faktör yüklerinin toplamının kareleri/ (Fornell ve Larcker, 1981, s.40-42) 


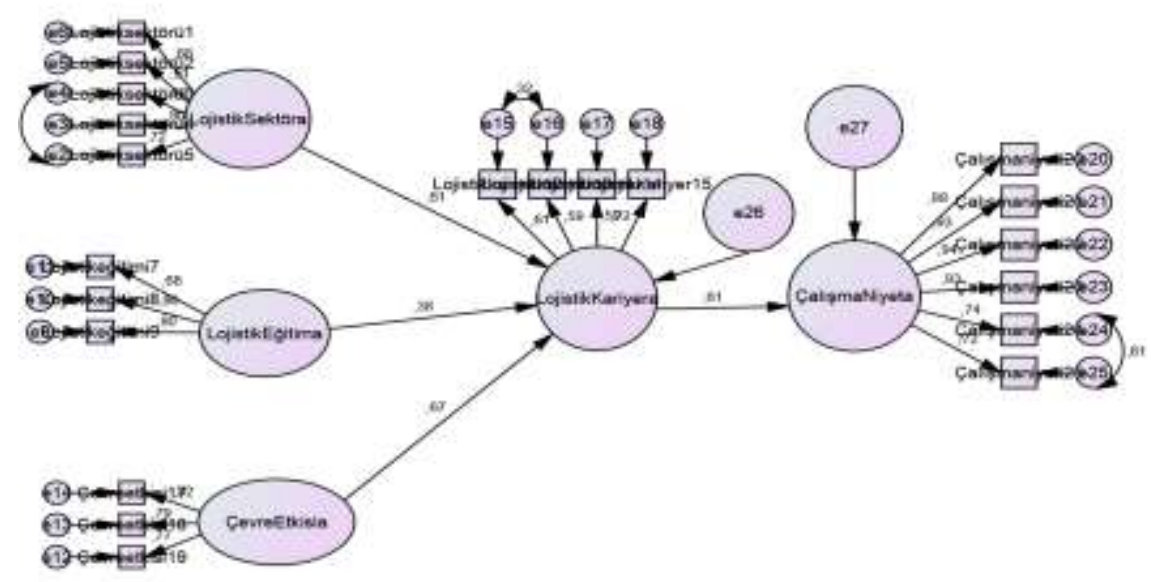

Şekil 2. Araştırma modeli

Araştırmada kullanılan ölçeklerin, Cronbach Alfa katsayıları göre oldukça yüksek derecede güvenilir olduğu tespit edilmiştir.

Tablo-5' deki uyum iyiliği indekslerinde görüldüğü üzere, model uyumunun tamamının çok iyi derecede olduğu ifade edilebilmektedir. Elde edilen sonuçlar; ortaya konulan kavramsal modelin veriler ile uyum gösterdiği, yapılan anket sayısının model için yeterli olduğu ve modelin istatistiksel olarak kabul edilebilir ve anlamlı olduğunu göstermektedir. Çalışma neticesinde, araştırma modelinde sunulan hipotezlerin değerlendirilmesi için modelin istatistiksel olarak geçerli bir model olduğu ortaya konulmuştur.

Yapısal eşitlik modelinin analizi sonucunda; öğrencilerin lojistik sektörüne bakışı lojistik sektöründe kariyer yapma isteğini pozitif yönde anlamlı olarak etkilediği; öğrencilerin okulda aldıkları eğitimin lojistik sektöründe kariyer yapma isteğini pozitif yönde anlamlı olarak etkilediği; öğrencilerin çevre etkisinin lojistik sektöründe kariyer yapma isteğini pozitif yönde anlamlı olarak etkilediği; öğrencilerin lojistik sektöründe kariyer yapma isteği ile lojistik sektöründe çalışma niyetini pozitif yönde anlamlı olarak etkilediği bulgularına ulaşılmıştır. Hipotezlere ait standardize regresyon ağırlığına ve model uyum değerlerine bakıldığında istatistiksel bakımından anlamlı olduğunu göstermektedir. Analiz sonucunda araştırma hipotezleri desteklenmiştir. 


\section{Sonuç ve Tartışma}

Bu çalışmanın amacı lojistik öğrencilerinin lojistik sektöründen beklentilerini incelemek ve çkan sonuçlar doğrultusunda önerilerde bulunmaktır. Anket sonuçları incelendiğinde sonuçların anlamlı ve pozitif yönde olduğu belirlenmiştir. Yapılan çalışmalar staj, okulda uygulanan müfredat öğrencilerin beklentilerini karşlayabilecek nitelikte ve öğrencileri sektöre hazırlayıcı durumda olduğu belirtilmiştir. Anket sonuçlarına göre öğrenciler danışmalıklarla ilgili cevaplarından yola çıkarak danışmanlıkların biraz daha iyileştirilmesi gerektiği sonucuna varılmıştır. Ayrıca eğitim kalitesini yükseltmek biraz daha ayrıntıya girmek ve öğrencilerin seminer ve eğitimlerle daha kapsamlı eğitim istediklerine sonucuna varılmıştır.

Bu çalışma, lojistik eğitimi alan Karamanoğlu Mehmetbey üniversitesi Sosyal Bilimler Meslek Yüksekokulu ve Uygulamalı Bilimler Yüksekokulu lojistik ve uluslararası ticaret ve lojistik yönetimi öğrencileri ve mezun olan öğrenciler ile sınırlandırılmıştır. Karaman'da sadece lojistik ve uluslararası ticaret ve lojistik yönetimi öğrencileri ile sınırlandırılan çalışmanın ilerde örneklem kütlesi genişletilerek farklı üniversite başka öğrenciler ve farklı lojistik dallarında okuyan öğrenciler ile yapılırsa faydaları artacaktır. Öğrencilerin lojistik sektöründen beklentilerini araştıran çalışmalar sınırlıdır. Bu konu hakkında çalışmalar genişletilerek öğrencileri sektör hakkında bilgilendirilmelidir. Sektörün de lojistik öğrencilerinin beklentilerini önemseyebilir ve bu konu hakkında çalışmalar yapabilmeleri önerilmektedir.

Öğrencilerin derslere karşı memnuniyetini arttırarak öğrencileri hem sektöre hem de sektöre ilişkin kariyer planlamasında yönlendirilebilir. Bu sayede öğrencilerin beklentilerine göre yönlendirme yapılır ve hem kaliteli personel hem de daha bilgili eleman olmalarına fırsat verilebilir. Öğrenciler daha çok okuyarak değil görerek ve uygulayarak öğrenme gücüne sahiptirler. Bu sebepten dolayı seminer, konferans ve etkinlikler genişletilerek öğrencilerin derslere yoğunlaştıılması sağlanabilir. Öğrenciler bu sayede sektöre hızlı ve bilinçli bir şekilde girebilirler. Ankete katılan katılımcılardan kadınların büyük çoğunluğu sektörde çalışabilmek için cinsiyet ayrımcllığ1 yoktur sorusuna katılmıyorum cevabını vermişlerdir. Öğrenciler bu konu hakkında da bilgilendirilmeli ve sektörde cinsiyet ayrımcılığı olmadığı anlatılabilir. 
Öğrencilerin geniş bir kitlesi de lojistiğin toplum tarafından yük taşımac1lığı olarak görüldüğünü belirtmişlerdir. Konferans ve seminerler düzenlenerek lojistiğin sadece yük taşımacilığından ibaret bir konu olmadığı anlatılabilir. Öğrencileri sektörü sevdirerek daha zevkli ve mutlu bir şekilde çalışmaları sağlanabilir. Öğrencilerde dâhil olmak üzere lojistik sektörü hakkında toplum yeterli bilgi ve deneyimlere sahip değildir. Yeni çalışmalarla birlikte hem toplum hem de öğrenciler bilinçlendirilebilir. 


\title{
EXTENDED ABSTRACT
}

\section{Expectations of Students Who Prefer Logistics Department from Logistics Sector - Example of Karamanoğlu Mehmetbey University}

\author{
Ahmet Alper Sayın - Ümmü Küçük \\ Karamanoğlu Mehmetbey University
}

The logistics industry has been developing rapidly in recent years. For this reason, logistics activities that have started to be implemented in our country have dragged the businesses into a competitive environment (Dalgic, 2019, p.14). Logistics; it manages information systems such as order processing, purchasing, transportation, production plan and program, inventory management, delivery, distribution, warehouse management, material requirement planning, management response to the customer (Tuerxun, 2017, p.17).

The logistics sector is also of great importance for the economy of our country. As a result of the increase in trade volume in Turkey, it shows a very rapid development in the logistics industry and create employment (Parker, 2018, p.1).

Since there is not much information about the logistics sector today, there is a difficulty in the business choice of the sector. This study enables students who are trained at the undergraduate and associate degree level in the logistics department to have information about the sector by researching and measuring their expectations about the sector. The study provides important contributions in terms of helping students with their career planning and making suggestions for instructors to direct students to the profession.

The main mass of the research consists of undergraduate / graduate students who have studied or graduated from Karamanoğlu Mehmetbey University Logistics program. The admission of students to the undergraduate program started in the fall semester of 2018, the admission of students to the associate program began in the fall of 2013. The total number of students attending the associate and undergraduate program in 2019 is 93 . In the previous years, there are 242 graduate students from the associate degree program. Considering the number of students studying and graduating in the number 
of surveys conducted, it is seen that the number of samples is sufficient. Missing data is due to the fact that some of the graduate students' contact addresses have changed and they have not returned. Therefore, the number of questionnaire forms subject to the analysis is 232 pieces.

In analyzing the data obtained: reliability, factor analysis, and validity analysis were used, and structural equation modeling was used to test the research hypotheses.

Validity and reliability of all scales developed and used in this study were evaluated with the help of confirmatory factor analysis. Confirmatory factor analysis result; One item from 6 variables under the logistics industry, two items from 5 variables under the logistics education, one item from 5 variables under the logistics career, and one item from 7 variables under the intention to work were excluded from the model as a result. As a result of the analysis, the proposed modifications were made and the model fit values after the modification, AVE and CR values were found to be acceptable to measure the combination validity of the research model. In addition, the scales used in the study were found to be highly reliable compared to the Cronbach Alpha coefficients.

If it is analyzed in the goodness of fit indices, it can be stated that the whole model fit is very good. The results obtained: show that the conceptual model presented is compatible with the data, the number of questionnaires conducted is sufficient for the model and that the model is statistically acceptable and significant. As a result of the study, it has been demonstrated that the model is a statistically valid model for evaluating the hypotheses presented in the research model.

As a result of the analysis of the structural equation model: the students' perspective on the logistics sector positively affects their desire to pursue a career in the logistics sector, the education they receive at school positively affects the desire to pursue a career in the logistics sector, the environmental impact of the students positively affects the desire to pursue a career in the logistics sector, It was found that students' desire to pursue a career in logistics sector positively and significantly affect their intention to work in logistics sector. When the standardized regression weight and model fit values of the hypotheses are analyzed, it is seen that they are statistically significant. As a result of the analysis, research hypotheses were supported.

The issues determined as a result of the study are as follows: 
- The scope of work is limited to students of Karamanoğlu Mehmetbey University Vocational School of Social Sciences and School of Applied Sciences, Logistics and International Trade and Logistics Management and graduates. In later studies, if the sample size is expanded and it is done with different university students and students studying in different logistics branches, its contribution to academic studies will increase.

- Studies investigating students' expectations from the logistics industry are limited. Studies on this subject should be expanded and students should be informed about the sector. The industry may also care about the expectations of the logistics students and it is recommended to work on this subject.

- By increasing the satisfaction of the students towards the lessons, the students can be directed both in the sector and in the sector related career planning. In this way, students are guided according to their expectations and they can be given the opportunity to become both qualified staff and more knowledgeable staff.

- Students have the power to learn by seeing and practicing rather than reading. Because of this reason; By extending seminars, conferences and events, students can concentrate on lessons. In this way, students can enter the sector quickly and consciously.

- The vast majority of women answered "I do not agree" to the question that there is no gender discrimination in order to work in the sector. Students should be informed about this issue and it can be explained that there is no gender discrimination in the sector.

- A wide audience of students stated that logistics is seen as a freight transport by the society. By conferences and seminars, it can be explained that logistics is not just a matter of freight transport. By making students love the industry, they can work more enjoyably and happily.

- The society does not have sufficient knowledge and experience about the logistics sector, including students. With new studies, both society and students can be made conscious. 


\section{Kaynakça / References}

Akan, E. (2015). Lojistik sektöründe entegre yönetim sistemi (Iso 9001, Ohsas 18001 ve Iso 10002) Uygulaması, Yüksek Lisans Tezi, İstanbul Aydın Üniversitesi, Fen Bilimleri Enstitüsü, İş Sağlığı ve Güvenliği Anabilim Dalı İş Sağlığı ve Güvenliği Programı.

Akyüzoğlu, D. (2008). Anadolu Öğretmen Liselerini tercih eden öğrencilerin beklentileri ve bu beklentilerin gerçekleşme düzeyi. Yeditepe Üniversitesi Sosyal Bilimler Enstitüsü.

Ayata, D. (2019). Lojistik sektörü uyuşmazlıkları ve arabuluculuk. Yüksek Lisans Tezi, Altınbaş Üniversitesi, Sosyal Bilimler Enstitüsü.

Babacan, M. (2003). Lojistik sektörünün ülkemizdeki gelişimi ve rekabet vizyonu. Ege Akademik Bakış Dergisi, 3(1), 8-15.

Baki, A., Akandere, G., Çetin, C., ve Demiralay, T. (2017). Türkiye açısından meslek yüksekokullarının önemi ve öğrenci tutumlarının değerlendirilmesi. Journal of Current Researches on Social Sciences, 7(2), 287-306.

Balc1, A. (2001). Sosyal bilimlerde araştırma, Pegem Yayıncilik, Ankara.

Bandura, A. (1997). Self-efficacy: The exercise of control. New York: Freeman and Company.

Baş, T. (2001). Anket nasıl yapılır, uygulanır, değerlendirilir?, Ankara:Seçkin Yayınalık. Bulut, Ö. (2007). Türkiye'de taşımacılık sektörünün lojistik olgusu içerisinde incelenmesi. Yüksek Lisans Tezi, Kadir Has Üniversitesi, İşletme Yönetimi Anabilim Dalı, Sosyal Bilimler Enstitüsü, 109-110.

Çavuş, Ş., ve Kaya, A. (2015). Turizm lisans eğitimi alan öğrencilerin kariyer planları ve turizm sektörüne yönelik tutumu. Manas Sosyal Araştırmalar Dergisi, 4(5), 101-117.

Çarıkçı, İ. H., ve Morçin, S. E. (2014). Önlisans turizm öğrencilerinin kariyer değerleri: Sarıkamışörneği. Elektronik Mesleki Gelişim ve Araştırmalar Dergisi, 2(2), 67-81.

Çevik, O. ve Gülcan, B. (2011). Lojistik faaliyetlerin çevresel sürdürülebilirliği ve Marco Polo programı. Karamanoğlu Mehmetbey Üniversitesi Sosyal ve Ekonomik Araştırmalar Dergisi, 1, 35-44.

Çıkmak, S. (2016). Türkiye'de lojistik eğitiminin durumu ve lojistik eğitiminin geliştirilmesine yönelik öneriler, Recep Tayyip Erdoğan Üniversitesi Sosyal Bilimler Dergisi, 2(3), 1-13.

Dalgıç, Y. (2019). Lojistik sektörü çalışanlarının algısındaki liderlik tarzlarn ile çalışanların işten ayrılma niyeti arasındaki ilişkinin incelenmesine yönelik bir araştırma, Yüksek Lisans Tezi, Altınbaş Üniversitesi, Sosyal Bilimler Enstitüsü. 
Dinçer, F., İ., Akova, O., ve Kaya, F., (2015). Meslek Yüksekokulu Turizm ve Otel İşletmeciliği programı öğrencilerinin kariyer planlaması üzerine bir araştırma: İstanbul Üniversitesi ve Gümüşhane Üniversitesi örneği. Elektronik Mesleki Gelişim ve Araştırmalar Dergisi, 1(2), 45-56.

Duman, T., Tepeci, M., ve Kamil, U., (2006). Mersin'de Yükseköğretim ve Orta Öğretim Düzeyinde turizm eğitimi almakta olan öğrencilerin sektörün çalışma koşullarını algılamaları ve sektörde çalışma isteklerinin karşılaştırmalı analizi. Anatolia: Turizm Araştırmaları Dergisi, 17(1), 51-69.

Dursun, Y., ve Kocagöz, E. (2010). Yapısal eşitlik modellemesi ve regresyon: Karşılaştırmalı bir analiz. Erciyes Üniversitesi İktisadi ve İdari Bilimler Fakültesi Dergisi, 35, 1-17.

Dünyada Lojistik Sektörü. (Ağustos 2, 2018). Lojistikçinin sesi. https://www.lojistikcilerinsesi.biz/2018/08/02/lpi2018veturkiye/ adresinden 06 Kasım 2019 tarihinde alınmıştır.

Düzgün (2015). Mesleki ve Teknik Anadolu Liselerinde turizm eğitimi almakta olan öğrencilerin turizm sektörüne yönelik görüşleri ile kariyer değerleri arasındaki ilişkinin karşılaştırlması, Yüksek Lisans Tezi, Gaziantep Üniversitesi Sosyal Bilimler Enstitüsü Turizm İşletmeciliği Anabilim Dal,,

Farmer, G. (1995) U.S. Expected to lose share of world tourism market, Newsletter of the Travel and Tourism Research Association, 26.

Fornell, C., ve Larcker, D. F. (1981). Structural equation models with unobservable variables and measurement error: Algebra and statistics.

Gürdoğan, A., ve Atabey, S. (2015). Öğrencilerin meslek stajından memnuniyet düzeylerinin kariyer hedeflerine etkisi. Muğla Sttkı Koçman Üniversitesi İktisadi ve İdari Bilimler Fakültesi Ekonomi ve Yönetim Araştırmalar Dergisi, 4(1).

Koban E., ve Keser, H. Y. (2013). Rekabet edebilirlikte Türk Lojistik sektörünün istihdam yapısının analizi ve istihdama yönelik devlet destekleri. Çalı̧ma İlişkileri Dergisi, 4(2), 32-43.

Koban, E. (2018). Lojistik sektöründe pazarlama stratejilerinin rekabet avantajı (gücü) üzerinde etkisi. Yüksek Lisans Tezi, Altınbaş Üniversitesi, Sosyal Bilimler Enstitüsü, İşletme Anabilim Dalı.

Koyuncu, M., Fiksenbaum, L., Ronald J. B., ve Demirer, H. (2011). Predictors of commitment to careers in the tourism industry, Anatolia: An International Journal of Tourism And Hospitality Research, 19(2), 225-236

Kusluvan, S., ve Kusluvan, Z. (2000). Perceptions and attitudes of undergraduate tourism students towards working in the tourism industry in Turkey. Tourism Management, 21, 251-269 
Kuzgun, Y. (2000). Meslek danışmanlı̆̆ı kuramlar ve uygulamalar, Ankara: Nobel Yayınlarl,

Lambert, D. M., Stock, J. R., ve Ellram, L. M. (1998). Fundamentals of logistics management. Mcgraw-Hill/Irwin.

Lojistikte İstihdam Olanakları. (Ekim 10, 2015). Hürriyet. http://www.hurriyet.com.tr/ekonomi/lojistik-sektoru-1-milyona-yakinistihdam-sagliyor-30347005 adresinden 09 Ekim 2019 tarihinde alınmıştır.

Lojistik Ön Lisans Bölüm ve Taban Puanları (Temmuz 8, 2019). Taban Puanları https:/www.tabanpuanlari.xyz/lojistik-2-yillik-taban-puanlari/ adresinden 27 Ekim 2019 tarihinde alınmıştır.

Lojistik nedir ? (t.y). Borusan. https:/www.borusanlojistik.com/tr/haberler/lojistiknedir adresinden 11 Ekim 2019 tarihinde alınmıştır.

Lojistik Sektöründe İstihdam Olanakları. (Eylül 24, 2012).Lojistik hattı. http://www.lojistikhatti.com/haber/2012/09/lojistik-sektorunde-egitim-veistihdam adresinden 09 Ekim 2019 tarihinde alınmıştır.

Lojistik Sektöründe Yaşanan Teknolojik Gelişmeler Temmuz 12, 2019). Globelink. Web: https://www.globelink-unimar.com/lojistik-sektorunde-yasananteknolojik-gelismeler, adresinden 11 Ekim 2019 tarihinde alınmıştır.

Lojistik Tarihsel Gelişimi(t.y). Lojistikturk. http://www.lojisturk.net/guncel/lojistiktanimi-tarihsel-gelisimi-1341827844h.html Adresinden 09 Kasim 2019 tarihinde alınmıştır.

Mobius, M. (2003). The use of item parcelling in statistical analyses-a research example. In 2nd. European Conference on Research Methodology for Business and Management, 247-256.

Noe, R, A. (1999). İnsan kaynaklarının eğitim ve gelişimi, (C, Çetin, Çev,) İstanbul: Beta Yayınevi. Sayfa: 34 .

Orhan, A. (2015). Türkiye'de lisans düzeyinde turizm eğitimi alan öğrencilerin turizm sektörü ile ilgili algllarının çalışma niyetleri üzerindeki etkisinin belirlenmesi. Yüksek Lisans Tezi, Eskişehir Orhan Gazi Üniversitesi Sosyal Bilimler Enstitüsü Turizm İşletmeciliği Anabilim Dalı, Turizm

Özdamar, K., (1999). Paket programlarla istatistiksel veri analizi-I, Kaan Yayınları, 2. Bask1.

Özkanlısoy, Ö. (2018). Lojistik sektöründe çalışanlarmn örgütsel adalet algısının iş motivasyonuna etkisi örnek bir uygulama. Yüksek Lisans Tezi, Bahçeşehir Üniversitesi, Fen Bilimleri Enstitüsü, Tedarik Zinciri ve Yönetimi Anabilim Dalı. 
Pajares, F., ve Schunk, D. (2001). The development of academic self-efficacy. Wigfield \& J. Eccles (Eds.), Development of Achievement Motivation. San Diego: Academic Press.

Pehlivan, R. (2008). Lisans düzeyinde turizm eğitimi almakta olan öğrencilerin sektör ile ilgili tutumlarını mezuniyet sonrası kariyer seçimine etkisi. Adnan Menderes Üniversitesi, Sosyal Bilimler Enstitüsü.

Polat, O. (2018). Müşteri ilişkileri yönetiminin rekabet gücüne etkisi, Yüksek Lisans Tezi, Celal Bayar Üniversitesi, İşletme Anabilim Dalı Yönetim ve Organizasyon Programı, Sosyal Bilimler Enstitüsü, 1

Riegel, C., ve Dallas, M. (1998). Hospitality and tourism careers: a Blue print for success, Prentice Hall Inc.:New Jersey

Rodrigue, JP ve Hesse, M. (2007). Küreselleşmiş ticaret ve lojistikle ilgili Kuzey Amerika perspektifleri.küresel yük taşmachlğg: Intermodalite, e-ticaret, lojistik ve sürdürülebilirlik, ulaştırma ekonomisi. Yönetim ve Politika Serileri. Cheltenham, İngiltere: Edward Elgar Yayınları , 103-134.

Roe, A. (1956). The psychology of occupations, Wiley Press:New York.

Sarışık, M. (2007). Turizm sektöründe meslek sahibi olmaya yönelten etkenler: Meslek Yüksekokulu öğrencilerine yönelik bir çalısma. Anatolia: Turizm Araştırmaları Dergisi, 18(2), 143-160.

Schermelleh, E. Karin, M. ve Helfried-Müller, H. (2003). Evaluating the fit of structural equation models: Tests of significance and descriptive goodness of fit measures. Methods of Psychological Research Online, 8(2).

Schreuder, A. ve Al T. (1999). Careers: An organizational perspective. Juta Akedemic, South Africa.

Şimşir, Z., ve Tolga, S. (2018). Üniversite öğrencilerinin fakülte yaşamının nitelikleri, Akademik özyeterlikleri ve öznel iyi oluşları arasındaki yordayı ilişkiler.Marmara Üniversitesi Atatürk Eğitim Fakültesi Eğitim Bilimleri Dergisi, 48(48).

Tan, K. C., Kannan, V. R. ve Narasimhan, R. (2007). The impact of operations capability on firm performance, International Journal of Production Research, 45(21).

Tekin, Ç. M. (2019). Marka imajının marka güvenine etkisi İzmir'de lojistik sektörü örneği. Yüksek Lisans Tezi, Beykent Üniversitesi, İşletme Yönetimi Anabilim Dalı, Sosyal Bilimler Enstitüsü. 13.

Thuermer, K. E. (2003). Transport logistics. World Wide Shipping. July/August.

Timur, N. (1988). Sanayi işletmelerinde lojistik faaliyetlerin organizasyonu, Anadolu Üniversitesi İktisadi ve İdari Bilimler Fakültesi Yayınları No:58. Eskişehir. 
Tuerxun, G. (2017). Çin Halk Cumhuriyeti'nin lojistik sektörünü geliştirmek adina uyguladığı destekler. Yüksek Lisans Tezi, İstanbul Ticaret Üniversitesi, Sosyal Bilimler Enstitüsü.

Tuncer, M., (2011). Yükseköğretim gençliğinin gelecek beklentileri üzerine bir araştırma. International Periodical For The Languages, Literature and History of Turkish, 6(2), 935-948.

Tutar, E., Tutar, F., ve Yetişen, H. (2009). Türkiye'de lojistik sektörünün gelişmişlik düzeyinin seçilmiş AB Ülkeleri (Romanya ve Macaristan) ile karşılaştırmalı bir analizi. Karamanoğlu Mehmetbey Üniversitesi Sosyal ve Ekonomik Araştirmalar Dergisi, 2, 190-216.

Türkay, O., ve Yağc1, K. (2007). Turizm eğitimi alan öğrencilerin okulda ve turizm sektöründe öğrenmelerinin sektörden ayrlma eğilimlerine Etkisi. Dokuz Eylül Üniversitesi Sosyal Bilimler Enstitüsü.

Uğur, H. (2019). Birleşmiş Milletler küresel ilkeler sözleşmesi'nin yolsuzlukla mücadele başlklı ilkesinin lojistik sektöründe incelenmesi, Yüksek Lisans Tezi, İstinye Üniversitesi, İşletme Anabilim Dalı, Sosyal Bilimler Enstitüsü, 41.

Unctad, S. (2006). World investment report 2005, transnational corporations and the internationalization of R\&D. Foreign Trade Review, 40(4), 85-108.

Üzümcü, T. P.,Alyakut, Ö., ve Günsel, A. (2015). Turizm eğitimi alan öğrencilerin, mesleğin geleceğine ilişkin bakış açları. Balkesir University Journal of Social Sciences Institute, 18(33).

Wu, X., Chen, Y., Zhang J., ve Wang Y., (2012). On improving higher vocational college education quality assessment. 2012 International Conference on Medical Physics and Biomedical Engineering, 1128-1132.

\section{Kaynakça Bilgisi / Citation Information}

Sayın, A. A. ve Küçük, Ü. (2020). Lojistik bölümünü tercih eden öğrencilerin lojistik sektöründen beklentileri: Karamanoğlu Mehmetbey Üniversitesi örneği. OPUS-Uluslararası Toplum Araştırmaları Dergisi, 16(28), 1342-1373. DOI: 10.26466/opus.679831 